\title{
KARAKTERISTIK PENYEBAB KANKER PAYUDARA
}

\author{
Nirmala Sari ${ }^{l}$ \\ Prodi D III Kebidanan Fakultas Vokasi Universitas Baiturrahmah ${ }^{l}$ \\ e-mail: nirmalasari@jurkeb.unbrah.ac.id ${ }^{l}$
}

\begin{abstract}
Breast cancer is the second leading cause of death after cervical cancer. Based on data obtained from the Padang City Health Office regarding the incidence of breast cancer, in 2015 there was an increase of 69\%, namely there were 142 old cases and 99 new cases of breast cancer. Then in 2016, the incidence of breast cancer in the city of Padang has increased again by 73\%, namely to 252 old cases and 186 new cases of breast cancer. This study is to see the characteristics of the causes of breast cancer in hospitals. Tk III Dr. Reksodiwiryo Padang in 2017.

This type of research is conducted descriptive research. The sample technique used simple random sampling, namely simple random with a lottery technique. The type of data used is secondary data by collecting data from medical records of women treated and diagnosed with breast cancer using a checklist sheet data collection format. The analysis used univariate analysis.

The results showed that $80.4 \%$ of women with breast cancer aged $\geq 40$ years, $4.3 \%$ of women with breast cancer had a BMI $\geq 30,39.1 \%$ of women with breast cancer had menarche at $\geq 12$ years of age, $23.9 \%$ of women with breast cancer had no Having been pregnant and giving birth, $26.1 \%$ of women with breast cancer did not breastfeed their babies, $47.8 \%$ of women with breast cancer had a history of hormonal contraceptives that had been used for more than 5 years and $56.5 \%$ of women with breast cancer had a genetic history of breast cancer.

The incidence of breast cancer can be detected early by doing breast self-examination (BSE) and breast examination to the clinical (SADANIS) periodically in women who have breast cancer risk factors. Health workers are expected to increase promotional efforts regarding breast cancer risk factors in women.
\end{abstract}

Keywords: Breast Cancer, BMI, Breastfeeding, Hormonal Contraception.

\begin{abstract}
ABSTRAK
Kanker payudara merupakan penyebab kematian ke 2 setelah kanker rahim. Berdasarkan data yang diperoleh dari Dinas Kesehatan Kota Padang tentang kejadian kanker payudara, pada tahun 2015 terjadi peningkatan sebesar $69 \%$ yaitu terdapat 142 kasus lama dan 99 kasus baru kanker payudara. Kemudian pada tahun 2016, angka kejadian kanker payudara di Kota Padang mengalami peningkatan lagi sebesar $73 \%$ yaitu menjadi 252 kasus lama dan 186 kasus baru kanker payudara. Penelitian ini untuk melihat karakteristik penyebab kanker payudara di RS. Tk III Dr. Reksodiwiryo Padang Tahun 2017.

Jenis penelitian yang dilakukan penelitian deskriptif. Teknik sampel yang digunakan simple random sampling yaitu acak sederhana dengan teknik undian. Jenis data yang dipakai data sekunder dengan mengumpulkan data dari catatan rekam medik wanita yang dirawat dan terdiagnosa kanker payudara dengan menggunakan format pengumpulan data lembaran checklist. Analisis yang digunakan analisis univariat.

Hasil penelitian didapatkan $80,4 \%$ wanita kanker payudara berusia $\geq 40$ tahun, 4,3\% wanita kanker payudara memiliki IMT $\geq 30,39,1 \%$ wanita kanker payudara mengalami menarche pada usia $\geq 12$ tahun, 23,9\% wanita kanker payudara belum pernah hamil dan melahirkan, 26,1\% wanita kanker payudara tidak menyusui bayinya, $47,8 \%$ wanita kanker payudara memiliki riwayat kontrasepsi hormonal yang lama pemakaiannya lebih dari 5 tahun dan $56,5 \%$ wanita kanker payudara memiliki riwayat genetik kanker payudara.

Kejadian kanker payudara dapat dideteksi lebih awal dengan melakukan periksa Payudara sendiri (SADARI) dan periksa payudara ke klinis (SADANIS) secara berkala pada wanita yang memiliki faktor risiko kanker payudara. Tenaga kesehatan diharapkan meningkatkan upaya promotif tentang faktor risiko kanker payudara pada wanita.

Kata Kunci: Kanker Payudara, IMT, Menyusui, Kontrasepsi Hormonal
\end{abstract}

\section{PENDAHULUAN}

\section{Latar Belakang}

Kanker payudara adalah salah satu kanker yang sangat ditakutkan bagi perempuan di seluruh dunia, termasuk Indonesia. Kanker payudara merupakan pertumbuhan sel payudara yang tidak terkontrol karena perubahan abnormal dari gen yang bertanggung jawab atas pengaturan pertumbuhan sel. Secara normal, sel payudara tua akan mati dan digantikan oleh sel baru yang lebih ampuh, regenerasi sel ini berguna untuk mempertahankan fungsi payudara. ${ }^{(1,2)}$

Insiden kanker payudara menempati urutan kedua terbanyak pada wanita di dunia. Sejauh ini, 
kanker payudara paling sering diderita oleh wanita dengan perkiraan 1,67 juta kasus kanker baru yang didiagnosis pada tahun 2012 (25\% dari semua kanker). Kanker payudara dapat terjadi pada wanita baik di negara maju maupun negara berkembang, dengan kasus lebih banyak pada negara berkembang (883.000 kasus) dibandingkan dengan negara maju (794.000 kasus). Tingkat insiden bervariasi hampir empat kali lipat di seluruh wilayah dunia, dengan laju pertumbuhan mulai dari 27 per 100.000 di Afrika Tengah dan Asia Timur hingga 92 per 100.000 di Amerika Utara. Kanker payudara menempati urutan sebagai penyebab kelima kematian akibat kanker secara keseluruhan (522.000 kematian) dan merupakan penyebab kematian akibat kanker yang paling sering pada wanita di negara berkembang (324.000 kematian, $14.3 \%$ dari total). Saat ini, kanker payudara menjadi penyebab kedua kematian akibat kanker di negara maju (198.000 kematian, 15.4\%) setelah kanker paru-paru ${ }^{(3)}$

Sementara itu, berdasarkan Pathological Based Registration di Indonesia, kanker payudara menempati urutan pertama dengan frekuensi relatif sebesar 18,6\%. Angka kejadian kanker payudara di Indonesia adalah 12/100.000 wanita, sedangkan di Amerika adalah sekitar 92/100.000 wanita dengan mortalitas yang cukup tinggi yaitu 27/100.000 atau 18 $\%$ dari kematian yang dijumpai pada wanita. Penyakit ini juga dapat diderita pada laki - laki dengan frekuensi sekitar 1\%. Di Indonesia, lebih dari $80 \%$ kasus ditemukan berada pada stadium yang lanjut, sehingga upaya pengobatan sulit dilakukan ${ }^{(4)}$

Berdasarkan data yang penulis peroleh dari Dinas Kesehatan Kota Padang tentang kejadian kanker payudara, pada tahun 2015 terjadi peningkatan sebesar 69\% yaitu terdapat 142 kasus lama dan 99 kasus baru kanker payudara. Kemudian pada tahun 2016, angka kejadian kanker payudara di Kota Padang mengalami peningkatan lagi sebesar $73 \%$ yaitu menjadi 252 kasus lama dan 186 kasus baru kanker payudara. ${ }^{(5)}$

Rumah Sakit Tk. III Dr. Reksodiwiryo Padang merupakan sebuah Rumah Sakit yang mempunyai fasilitas kesehatan yang memadai,juga sebagai Rumah Sakit Pendidikan di Sumatera Barat. Berdasarkan Data Rekam Medik RS. Tk. III Dr. Reksodiwiryo Padang tahun 2017 kunjungan pasien kanker payudara di instalasi rawat inap RS. Tk. III Dr. Reksodiwiryo Padang sebesar 84 orang. ${ }^{(6)}$

Sampai saat ini belum diketahui secara pasti apa yang menyebabkan kanker ini terjadi, tetapi ada faktor risiko yang menyebabkan seorang wanita menderita kanker payudara. Risiko kanker payudara pada wanita diantaranya usia menarche, usia menopause, usia kehamilan pertama, lama menyusui, kontrasepsi hormonal, aktivitas fisik, riwayat merokok, tingkat stress, obesitas, dan pola makan ${ }^{(7)}$

Masalah utama dalam penanggulangan kanker adalah kurangnya pengetahuan masyarakat tentang kanker dan kesadaran masyarakat untuk melakukan perilaku hidup sehat untuk mengurangi risiko kanker serta melakukan deteksi dini kanker.
Akibatnya sebagian besar kanker ditemukan pada stadium lanjut dan sulit ditanggulangi, sehingga memberikan beban yang besar bagi pasien kanker dan keluarganya ${ }^{(8)}$

\section{METODE}

Penelitian ini merupakan penelitian deskriptif untuk mengetahui karakteristik penyebab kanker payudara di Rumah Sakit Tentara dr. Reksodiwiryo Padang Tahun 2017. Populasi dalam penelitian ini adalah seluruh wanita yang terdiagnosa kanker payudara dan dirawat inap di RS. Tk. III Dr. Reksodiwiryo Padang selama tahun 2017 yang berjumlah 46 orang. Jenis data yang di pakai pada penelitian ini adalah jenis data sekunder. Teknik pengumpulan data dalam penelitian ini yaitu melalui studi dokumentasi (catatan rekam medik) wanita yang dirawat dan terdiagnosa kanker payudara dengan menggunakan format pengumpulan data (cheklist). Pengumpulan data yang dikumpulkan adalah umur ibu, IMT (indeks massa tubuh), riwayat kontrasepsi hormonal, usia menarche, paritas, riwayat menyusui dan riwayat genetik kanker payudara. Data dianalisis secara univariat.

\section{HASIL}

Berdasarkan hasil penelitian didapatkan $80,4 \%$ responden kanker payudara berusia $\geq 40$ tahun dan $19,6 \%$ berusia $<40$ tahun. Berdasarkan IMT didapatkan 4,3\% responden kanker payudara memiliki IMT $\geq 30$ dan 95,7\% memiliki IMT < 30. Berdasakan usia menarche didapatkan $39,1 \%$ responden kanker payudara mengalami menarche pada usia $\geq 12$ tahun dan $60,9 \%$ mengalami menarche pada usia $<12$ tahun. Berdasakan jumlah paritas didapatkan 23,9\% responden kanker payudara belum pernah hamil dan melahirkan, dan 76,1\% sudah pernah hamil dan melahirkan. Berdasarkan riwayat menyusui 26,1\% responden kanker payudara tidak menyusui bayinya dan $73,9 \%$ pernah menyusui bayinya. Berdasarkan riwayat penggunaan kontrasepsi hormonal 47,8\% responden kanker payudara pernah menggunakan kontrasepsi hormonal lebih dari 5 tahun dan 52,2\% menggunakan kontrasepsi hormonal kurang dari 5 tahun. Berdasarkan riwayat genetik kanker payudara $56,5 \%$ responden kanker payudara memiliki riwayat genetik mengalami kanker payudara dan $43,5 \%$ tidak memiliki riwayat genetik mengalami kanker payudara.

Tabel 1. Karakteristik Penyebab Kanker Payudara

\begin{tabular}{lcc}
\hline $\begin{array}{l}\text { Karakteristik Penyebab } \\
\text { Kanker Payudara }\end{array}$ & f & \% \\
\hline Usia & & \\
$\geq 40$ thn & 37 & 80,4 \\
$<40$ thn & 9 & 19,6 \\
Total & 46 & 100 \\
\end{tabular}


Vol. 16 No. 1 Januar i - April 2021

\begin{tabular}{|c|c|c|}
\hline \multicolumn{3}{|l|}{ IMT } \\
\hline$\geq 30$ & 2 & 4,3 \\
\hline$<30$ & 44 & 95,7 \\
\hline Total & 46 & 100 \\
\hline \multicolumn{3}{|l|}{ Usia Menarche } \\
\hline$<12$ thn & 18 & 39,1 \\
\hline$\geq 12$ tahun & 28 & 60,9 \\
\hline Total & 46 & 100 \\
\hline \multicolumn{3}{|l|}{ Jumlah Paritas } \\
\hline Belum pernah melahirkan & 11 & 23,9 \\
\hline Pernah melahirkan & 35 & 76,1 \\
\hline Total & 46 & 100 \\
\hline \multicolumn{3}{|l|}{ Riwayat Menyusui } \\
\hline Tidak pernah & 12 & 26,1 \\
\hline Pernah & 34 & 73,9 \\
\hline Total & 46 & 100 \\
\hline Kontrasepsi & & \\
\hline \multicolumn{3}{|l|}{ Hormonal } \\
\hline$\geq 5$ tahun & 22 & 47,8 \\
\hline$<5$ tahun & 24 & 52,2 \\
\hline Total & 46 & 100 \\
\hline \multicolumn{3}{|l|}{ Riwayat Genetik } \\
\hline Ada & 26 & 56,5 \\
\hline Tidak ada & 20 & 43,5 \\
\hline Total & 46 & 100 \\
\hline
\end{tabular}

\section{PEMBAHASAN}

Berdasarkan hasil penelitian didapatkan, 37 $(80,4 \%)$ responden berusia $\geq 40$ tahun. Hasil penelitian ini didukung dengan penelitian yang dilakukan oleh Azamris (2006) yang dilakukan di RS M. Djamil Padang dengan desain case control, diperkirakan risiko kelompok usia $\geq 40$ tahun terkena kanker payudara 1,35 kali lebih tinggi dibandingkan dengan kelompok wanita usia $<40$ tahun ${ }^{(8)}$

Pada rentang usia 40-49 tahun memiliki risiko kanker payudara 1 dari 69 wanita. Sedangkan pada rentang usia 30-39 tahun memiliki faktor risiko terkena kanker 1dari 223 wanita. Hal ini menyimpulkan bahwa semakin tua usia wanita, semakin tinggi risiko terkena kanker payudara. ${ }^{(2)}$

Tingginya risiko kanker payudara pada usia tua menunjukkan bahwa, hormone reproduksi yang diproduksi oleh ovarium dan kelenjar adrenal terlibat dalam pathogenesis kanker payudara. Hal ini karena kanker yang tidak responsif terhadap hormone tidak menunjukkan perubahan kejadian yang berarti selama periode reproduksi wanita. ${ }^{(9)}$

Hasil penelitian didapatkan karakteristik usia responden sebagai berikut : 9 orang dengan usia $40-$ 49 tahun, 22 orang dengan usia 50 -59 tahun dan 6 orang dengan usia $60-69$ tahun. Usia dikelompokkan menjadi 2 kategori yaitu, usia $\geq 40$ tahun dan $<40$ tahun. Risiko kanker payudara akan semakin bertambah sebanding dengan pertambahan usia.

Berdasarkan hasil penelitian didapatkan 2 $(4,3 \%)$ responden memiliki IMT $\geq 30$. Seorang wanita yang mengalami obesitas setelah menopause akan berisiko 1,5 kali lebih besar untuk terkena kanker payudara dibandingkan dengan wanita berberat badan normal ${ }^{(10)}$

Obesitas adalah kegemukan yang diakibatkan oleh kelebihan lemak dalam tubuh. Obesitas memiliki kaitan erat dengan peningkatan risiko kanker payudara, terutama bagi perempuan setelah menopause. Jaringan lemak tubuh merupakan sumber utama estrogen setelah ovarium berhenti menghasilkan hormone. Memiliki jaringan lemak lebih banyak berarti memiliki estrogen lebih tinggi yang meningkatkan risiko kankerpayudara. (2)

Menurut hasil penelitian resiko berat badan terdapat 2 orang dengan berat badan obesitas dengan IMT (Indeks Massa Tubuh) > 30. Berat badan dan tinggi badan responden diperoleh dari catatan rekam medik saat melakukan penelitian yang di kategorikan menjadi 2 yaitu, obesitas bila IMT $\geq 30$ dan tidak obesitas bila IMT < 30. Dari hasil penelitian penyebab kanker payudara tidak hanya terjadi pada orang obesitas hal ini dapat terjadi karena faktor resiko lain yang dapat mengakibatkan kanker payudara dan tidak diteliti dalam penelitian seperti pola makan yang tidak sehat sehingga tidak menutup kemungkinan responden yg tidak mempunyai riwayat obesitas bisa menderita kanker payudara.

Berdasarkan hasil penelitian didapatkan 18 $(39,1 \%)$ responden mengalami menarche pada usia < 12 tahun Hasil penelitian ini sama dengan penelitian yang dilakukan oleh Priyatin, dkk (2013) tentang faktor resiko yang berpengaruh terhadap kejadian kanker payudara di RSUP Dr. Kariadi Semarang terdapat 23,7 $\%$ usia menarche yang berisiko kanker payudara ${ }^{(11)}$

Siklus ovarium wanita setiap bulannya akan menjadi karsinogeneik bagi payudara jika hal ini berlangsung lebih awal. Hal ini dipengaruhi oleh siklus hormonal yang terjadi pada organ reproduksi wanita dan reseptor estrogen yang ada pada payudara akibat dari overekspresi protein payudara. Menarche pada umur dini dapat meningkatkan risiko kanker dan sebaliknya, menarche terlambat dapat mengurangi risiko kanker payudara. ${ }^{(1)}$

Menurut hasil penelitian usia menarche dikelompokkan menjadi 2 kategori, yaitu usia menarche $<12$ tahun dan usia menarche $\geq 12$ tahun. Umur menstruasi < 12 tahun secara signifikan meningkatkan resiko kanker payudara, karena umur menstruasi yang lebih awal dan menopause yg terlambat berhubungan dengan lamanya paparan hormon estrogen dan progesteron pada wanita yang 
berpengaruh terhadap proses proliferasi jaringan termasuk jaringan payudara.

Berdasarkan hasil penelitian didapatkan 11 $(23,9 \%)$ responden yang belum pernah melahirkan. Selama kehamilan prolakin akan banyak disekresi, dan dipengaruhi oleh hormone lain seperti estrogen, progesterone, human placenta lactogen, dan cortisol untuk merangsang pertumbuhan payudara untuk berdiferensiasi dengan cepat dan proliferasi yang cepat pada epithelium payudara. Risiko kanker payudara akan berkurang pada kehamilan dan paritas yang tinggi hingga setengah dari risiko wanita yang tidak pernah melahirkan. ${ }^{(11,13)}$

Menurut hasil penelitian paritas yang dimaksud adalah berapa jumlah anak dimiliki oleh responden. Paritas dikelompokkan menjadi 2 kategori yaitu, tidak memiliki anak (nulipara) atau punya satu anak (primipara) dan multipara.

Wanita yang hamil diusia lebih dari 30 tahun dapat meningkatkan risiko kanker payudara karena keterpaparan hormon estrogen yang lama pada wanita tersebut. Setelah kehamilan risiko kanker payudara akan semakin berkurang jika wanita tersebut menyusui bayinya. Karena dengan menyusui akan menekan produksi estrogen oleh hormone prolactin. Risiko kanker payudara pada wanita usiayang hamil lebih dari 30 tahun dapat dicegah salah satunya dengan pemeriksaan rutin yang dilakukan ke ptugas kesehatan untuk mendeteksi dini kanker payudara.

Berdasarkan hasil penelitian didapatkan 12 $(26,1 \%)$ responden tidak menyusui bayinya. Hasil penelitian ini didukung dengan penelitian yang dilakukan oleh Anggorowati (2013) tentang faktor risiko kanker payudara wanita yang mana terdapat 38,2 $\%$ responden yang riwayat menyusui berisiko ${ }^{(14)}$

Wanita yang menyusui setidaknya 12 bulan mengurangi risiko kanker payudara sebanyak 33\% dibandingkan dengan wanita yang tidak menyusui. Laktasi dapat menekan terjadinya pengembangan kanker payudara dengan mengurangi dan menekan produksi estrogen ${ }^{(13)}$

Menyusui sangat penting bagi pertumbuhan dan perkembangan bayi. Namun ternyata tidak hanya bermanfaat bagi bayi tetapi juga bagi sang ibu. Menurut hasil penelitian riwayat menyusui yang dimaksud adalah lama responden menyusui anaknya yang dibagi menjadi 2 kategori yaitu, tidak pernah menyusui atau menyusui lebih $<2$ tahun dan menyusui lebih dari $>2$ tahun. Waktu menyusui yang lebih lama mempunyai efek yang positif dalam menurunkan risiko kanker payudara melalui siklus pengeluaran hormone prolactin karena isapan bayi sehingga mengakibatkan tertekannya hormone estrogen.

Berdasarkan hasil penelitian didapatkan 22 $(47,8 \%)$ responden memiliki riwayat kontrasepsi hormonal yang lama pemakaiannya lebih dari 5 tahun. Hasil penelitian ini didukung dengan penelitian yang dilakukan oleh Abidin, dkk (2014) tentang faktor risiko kejadian kanker payudara di RSUD Labuang Baji
Makassar ditemukan $62 \%$ responden yang memiliki riwayat kontrasepsi hormonal yang berisiko ${ }^{(15)}$

Kontrasepsi hormonal mengandung estrogen dan progesterone yang akan memberi efek proliferasi berlebih pada duktus ephitelium payudara, berlebihnya proses proliferasi bila di ikuti dengan hilangnya kontrol atas proliferasi sel dan pengaturan kematian sel yang sudah terprogram akan mengakibatkan sel payudara berproliferasi secara terus menerus tanpa adanya batas kematian. Hilangnya fungsi kematian sel yang terprogram ini akan menyebabkan ketidakmampuan mendeteksi kerusakan sel akibat adanya kerusakan pada DNA, sehingga sel-sel abnormal akan berproliferasi secara terus -menerus tanpa dapat dikendalikan ${ }^{(15)}$

Menurut hasil penelitian riwayat pemakaian kontrasepsi hormonal yang dimaksud adalah lama pemakaian pil dan suntik yang pernah digunakan oleh responden. Pemakaian riwayat kontrasepsi hormonal dikelompokkan menjadi 2 kategori, yaitu pernah menggunakan kontrasepsi hormonal selama $\geq 5$ tahun dan $<5$ tahun. Faktor resiko penggunaan kontrasepsi hormonal akan meningkat sehubungan dengan lamanya waktu penggunaan yang menyebabkan terjadinya peningkatan paparan hormone estrogen pada tubuh yang dapat memicu pertumbuhan sel secara tidak normal seperti kanker payudara. Namun dari penelitian ada juga beberapa responden yang menggunakan kontrasepsi hormonal $<5$ tahun.

Wanita yang memiliki one degree relatives (keturunan di atasnya) yang menderita/pernah menderita kanker payudara atau kanker indung telur memiliki risiko kanker payudara yang lebih tinggi. Namun, kanker payudara bukan penyakit keturunan seperti diabetes melitus atau hemofilia maupun alergi. Walaupun demikian, gen yang dibawa wanita penderita kanker payudara mungkin saja dapat diturunkan sekitar $5-10 \%$. $^{(16)}$

Menurut hasil penelitian riwayat genetika yang dimaksud adalah riwayat keluarga yang menderita kanker payudara. Bila ibu, saudara wanita mengidap kanker payudara maka ada kemungkinan untuk memiliki risiko terkena kanker payudara dua kali lipat dibandingkan wanita lain yang tidak mempunyai riwayat keluarga yang terkena kanker payudara Jadi, ada beberapa keluarga yang memiliki risiko terkena kanker lebih tinggi dibandingkan dengan keluarga lainnya.

\section{KESIMPULAN}

Berdasarkan hasil penelitian didapatkan sebagian besar responden kanker payudara 80,4\% berusia $\geq 40$ tahun, sebagian kecil responden kanker payudara $4,3 \%$ memiliki IMT $\geq 30$, sebagian kecil responden kanker payudara 39,1\% mengalami menarche pada usia $\geq 12$ tahun, sebagian kecil responden kanker payudara $23,9 \%$ belum pernah hamil dan melahirkan, sebagian kecil responden kanker 
payudara $26,1 \%$ tidak menyusui bayinya, hampir separoh responden kanker payudara 47,8\% memiliki riwayat kontrasepsi hormonal yang lama pemakaiannya lebih dari 5 tahun dan setengah dari responden $56,5 \%$ memiliki riwayat genetic kanker payudara. Kejadian kanker payudara dapat dideteksi lebih awal dengan melakukan periksa Payudara sendiri (SADARI) dan periksa payudara ke klinis (SADANIS) secara berkala pada wanita yang memiliki faktor risiko kanker payudara. Tenaga kesehatan diharapkan meningkatkan upaya promotif tentang faktor risiko kanker payudara pada wanita.

\section{DAFTAR PUSTAKA}

1. Kementrian Kesehatan RI Pusat Data dan Informasi Kesehatan. (2016). Bulan Peduli Kanker Payudara . Infodatin Kanker

2. Putra. RS. (2015). Buku Lengkap Kanker Payudara: Yogyakarta: Laksana.

3. International Agency for Research on Cancer. (2012). Lates global cancer data.

4. Kementrian Kesehatan RI. 2012. Profil Kesehatan Indonesi. Jakarta.

5. Dinas Kesehatan Provinsi Sumatera Barat. (2017). Data Kanker Payudara.

6. Medical Record RST TK III dr Reksodiwiryo. (2017)

7. Haslinda, Erna Kadrianti, Suarnianti. 2013. Faktor Risiko Kejadian Kanker Payudara di RSUP DR. Wahidin Sudiruhusodo Makssar. Jurnal Ilmiah Kesehatan Diagnosis. Vol 2 No 1:19

8. Alfita, Dewi. (2017). Faktor Risiko Penyakit Kanker Payudara di Wilayah Asia (Dengan Pendekatan Studi Meta Analisis). Jurnal Kesehatan Andalas. Vol 13. pp 1-8

9. Abdulkareem. I.H. (2013). Aetio-pathogenesis of breast cancer. Nigerian Medical Journal Vol 54.pp.371-376. Issue.6. Doi: 10.4103/03001652.126284

10. Olfah, Yustiana, dkk. 2013. Kanker Payudara dan Sadari. Yogyakarta: Nuha Medika

11. Priyatin. (2013). Faktor Risiko yang Berpengaruh Terhadap Kejadian Kanker Payudara di RSUP DR. Kariadi Semarang

12. Fritz and speroof. (2011). Clinical Gynecologic Endocrinoloy and infertility. $8^{\text {th }}$ ed. Philadelphia: Lippincott Williams and Wilkins pp. 995-1000

13. Laamiri, F. Z., Bouayad, A., Hasswane, N., Ahid, S. (2015). Risk Factors for Breast
Cancer of Different Age Groups : Moroccan Data. Journal of Obstetrics and Gynecology. pp79-87. Doi: 10.4236/ojog.2015.52011

14. Anggrowati, Lindra. (2013). Faktor Risiko Kanker Payudara Wanita. Jurnal Kesehatan Masyarakat. Vol 8, No 2. pp 121-126.

15. Abidin, H.Syahrir, Richa. 2014. Faktor Resiko Kejadian Kanker Payudara di RSUD Labuang Baji Makasar. Makasar: Jurnal Ilmiah Kesehatan Diagnosis. Vol 4 no 2: 236242.

16. Faida, Wilda Eka. (2016). Analisa Pengaruh Faktor Usia, Status Pernikahan dan Riwayat Keluarga Terhadap Pasien Kanker Payudara di Rumah Sakit Onkologi Surabaya. Jurnal Manajemen Kesehatan Yayasan RS. Dr. Soetomo 2 (1), 1-7, 2016. Vol 2 No 1. 